\title{
The analysis of selected parameters of sleep in the population of adolescents in school-age
}

Analiza wybranych parametrów snu w populacji młodzieży szkolnej

\author{
'Blessed Rafał Chyliński Municipal Centre for Therapy and Health Prophylaxis, Łódź, Poland \\ ${ }^{2}$ State University of Applied Sciences in Konin, Konin, Poland \\ ${ }^{3}$ Department of Adolescent Psychiatry, $1^{\text {jt }}$ Chair of Psychiatry, Medical University of Lodz, Łódź, Poland \\ Correspondence: Bogna Andrzejczak, Blessed Rafał Chyliński Municipal Centre for Therapy and Health Prophylaxis, Kilińskiego 232, 93-133 Łódź, Poland, e-mail: bogna@andrzejczak.pl
}

'Miejkkie Centrum Terapii i Profilaktyki Zdrowotnej im. bł. Rafała Chylińskiego, Łódź, Polska

2 Państwowa Wyższa Szkoła Zawodowa w Koninie, Konin, Polska

${ }^{3}$ Klinika Psychiatrii Młodzieżowej, I Katedra Psychiatrii, Uniwersytet Medyczny w Łodzi, Łódź, Polska

Adres do korespondencji: Bogna Andrzejzzak, Miejskie Centrum Terapii i Profilaktyki Zdrowotnej im. bł. Rafała Chylińskiego w Łodzi, ul. Kilińskiego 232, 93-133 Łódź, e-mail: bogna@andrzejczak.pl

\begin{abstract}
Aim: The study attempted to analyse selected parameters of sleep among students of secondary schools with taking into consideration the age and sex of the participants. Material: The study enrolled 125 students aged 12-18 from randomly selected secondary schools; $56 \%$ of the studied subjects were boys $(n=70)$, and $44 \%$ - girls $(n=55)$. Method: The students answered 18 questions included in the Sleep Disorders Assessment Questionnaire thus performing an independent, subjective assessment of sleep parameters and of their own behaviours which may affect sleep. Next, certain sleep parameters were compared between the group of girls and boys and between the group of early (12-14 years old) and late (15-18 years old) adolescents. Results: One in three surveyed persons reported the current or past occurrence of sleep disorders; over a half of these persons reported that these problems lasted for over a month. Over $50 \%$ of those surveyed declared that they sleep for less than 8 hours during one night. Nearly half of the students did not go to sleep at regular times and had prolonged sleep latency. The studied persons had the biggest problem with waking up in the morning. Nearly half of the study participants claimed that they wake up during the night, most frequently once or twice. Two third of those surveyed had the feeling that they sleep too short and over a half of them felt tired or sleepy during the day. More than $1 / 3$ of the studied subjects had the feeling of too shallow sleep. Statistically significant differences were noted between girls and boys in terms of the feeling of too short sleep, the feeling of tiredness during the day and the feeling of sleepiness during the day - in case of each of these parameters girls more frequently reported the occurrence of unfavourable phenomena. Only one statistically significant difference was found among the compared age groups - it referred to using psychoactive substances which were much more frequently taken by older adolescents. Conclusions: Problems with sleep are noticeable already among school-age adolescents and they are frequently of chronic nature. They were more frequently observed among the group of girls, no differences in sleep parameters were noted between the groups of younger and older adolescents.
\end{abstract}

Keywords: sleep, problems with sleep, adolescence, sex, students

Cel: $\mathrm{W}$ badaniu podjęto próbę analizy wybranych parametrów snu wśród uczniów szkół ponadpodstawowych z uwzględnieniem wieku i płci uczestników. Materiał: Przebadano 125 uczniów w wieku 12-18 lat z losowo dobranych szkół ponadpodstawowych; 56\% osób stanowili chłopcy $(n=70)$, a $44 \%$ - dziewczęta $(n=55)$. Metoda: Uczniowie odpowiadali na 18 pytań zawartych w Kwestionariuszu Oceny Zaburzeń Snu, dokonując samodzielnej, subiektywnej oceny parametrów snu i własnych zachowań mogących wpływać na sen. Następnie porównano określone parametry snu między grupą dziewcząt i chłopców oraz między grupą wczesnych (12-14 lat) i późnych adolescentów (15-18 lat). Wyniki: Co trzeci z ankietowanych zgłosił występowanie problemów ze snem; ponad połowa z tych osób podała, że problemy utrzymują się dłużej niż miesiąc. Ponad 50\% ankietowanych zadeklarowało, iż sypia krócej niż 8 godzin w ciągu jednej nocy. Blisko połowa uczniów nie kładła się spać o regularnych porach i miała wydłużoną latencję snu. Największą trudność sprawiało badanym poranne budzenie się. Blisko połowa uczestników stwierdziła, że wybudza się w nocy, przeważnie raz bądź dwa razy. Dwie trzecie ankietowanych miało poczucie zbyt krótkiego snu, a ponad połowa $\mathrm{z}$ nich czuła się zmęczona bądź senna w ciągu dnia. Więcej niż 1/3 badanych miało poczucie zbyt 
płytkiego snu. Między dziewczętami i chłopcami odnotowano istotne statystycznie różnice w zakresie poczucia zbyt krótkiego snu, poczucia zmęczenia w ciągu dnia oraz poczucia senności w ciągu dnia - w przypadku każdego z tych parametrów dziewczęta częściej zgłaszały występowanie niekorzystnych zjawisk. W porównywanych grupach wiekowych wykazano tylko jedną różnicę istotną statystycznie - dotyczyła ona używania substancji psychoaktywnych, po które znacznie częściej sięgali starsi adolescenci. Wnioski: Problemy ze snem są zauważalne już wśród młodzieży szkolnej i niejednokrotnie mają charakter przewlekły. Częściej obserwowano je w grupie dziewcząt, nie odnotowano różnic w parametrach snu między grupami młodzieży młodszej i starszej.

Słowa kluczowe: sen, problemy ze snem, adolescencja, płeć, uczniowie

\section{BACKGROUND}

$\mathrm{S}$ leep and wakefulness are the two possible physiological conditions of the human organism. Sleep is the functional condition of the central nervous system with periods of stillness and absence of awareness cyclically occurring and transient at a daily rhythm (Nowicki, 2002). Sleep is especially important during human development, including the puberty period - at this stage the sleeping pattern changes and becomes similar to that of an adult. The period of puberty is associated with hormonal changes, a change in the secretion of melatonin and the changing of the sleeping pattern. Moreover, new educational and social challenges contribute to the limiting of time devoted to sleep. Adolescents need about 9-9.25 hours of sleep. Among older teenagers there occurs a physiological delay of the sleeping phase by about 2 hours which results in delayed going to sleep and morning waking up (delayed sleepwake phase disorder, DSWPD) (Avidan and Zee, 2007). Some teenagers need a short nap in early afternoon hours which may also influence the deterioration of the parameters of night sleep (Meltzer and Mindell, 2006). Before the period of puberty the frequency of the occurrence of sleep disorders among girls and boys is the same whereas in the later period more sleep disorders were observed in the group of girls (Kasperczyk et al., 2006; Yarcheski and Mahon, 1994). Sleep disorders are also strongly associated with problems related to mental health such as mood disorders, anxiety disorders and adaptive disorders (Kaczor and Skalski, 2016; Kothare and Scott, 2017; Krysiak-Rogala and Jernajczyk, 2013; Sarchiapone et al., 2014; Urban, 2007). The frequency of the mentioned disorders increases with age, especially in the period of puberty, which may influence the deterioration of sleep parameters. Moreover, adolescence is the period of first contacts with psychoactive substances, the taking of which has got a potentially negative influence on the quality of sleep (Doghramji, 2006). In the available data bases the authors found only over a dozen publications related to the problem of sleep in the population of adolescents attending schools (Meijer et al., 2000; Saarenpää-Heikkilä et al., 1995; Sarchiapone et al., 2014; Wasserman, 2016). In studies of various populations of children sleeping disorders referred to $25-62 \%$ of persons and in the studies of populations of Polish children the frequency of sleep disorders ranged from 19-67\% (Kaczor and Skalski, 2016).

\section{WSTĘP}

$\mathrm{S}$ en jest jednym z dwóch - obok czuwania - stanów fizjologicznych, w którym może się znajdować organizm ludzki. To stan czynnościowy ośrodkowego układu nerwowego z cyklicznie pojawiającym się i przemijającym w rytmie dobowym zniesieniem świadomości i bezruchem (Nowicki, 2002). Sen jest szczególnie ważny w trakcie rozwoju człowieka, włącznie z okresem dojrzewania - na tym etapie wzorzec snu zmienia się i upodabnia do wzorca snu osoby dorosłej.

$\mathrm{Z}$ procesem dojrzewania wiążą się zmiany hormonalne, zmiana wydzielania melatoniny i zmiana wzorca snu. Dodatkowo nowe wyzwania szkolne i społeczne przyczyniają się do ograniczenia czasu przypadającego na sen. Adolescenci potrzebują 9-9,25 godziny snu. Wśród starszych nastolatków dochodzi do fizjologicznego przesunięcia fazy snu mniej więcej o 2 godziny, co skutkuje późniejszym kładzeniem się spać i opóźnionym rannym wstawaniem (delayed sleep-wake phase disorder, DSWPD) (Avidan i Zee, 2007). Niektórzy nastolatkowie potrzebują krótkiej drzemki w godzinach wczesnopopołudniowych, co także może wpływać na pogorszenie parametrów snu nocnego (Meltzer i Mindell, 2006). Przed okresem pokwitania częstość występowania zaburzeń snu wśród dziewcząt i chłopców jest taka sama, natomiast na etapie późniejszym wykazywano więcej zaburzeń snu w grupie dziewcząt (Kasperczyk et al., 2006; Yarcheski i Mahon, 1994). Zaburzenia snu są również silnie powiązane z problemami dotyczącymi zdrowia psychicznego, takimi jak zaburzenia nastroju, lękowe i adaptacyjne (Kaczor i Skalski, 2016; Kothare i Scott, 2017; Krysiak-Rogala i Jernajczyk, 2013; Sarchiapone et al., 2014; Urban, 2007). Częstość wymienionych zaburzeń wzrasta $z$ wiekiem, szczególnie w okresie dojrzewania, co może wpływać na pogorszenie parametrów snu. W okresie adolescencji dochodzi ponadto do pierwszych kontaktów z substancjami psychoaktywnymi, których zażywanie ma potencjalnie negatywny wpływ na jakość snu (Doghramji, 2006).

W dostępnych bazach danych znaleziono jedynie kilkanaście publikacji poruszających problem snu w populacji adolescentów uczęszczających do szkół (Meijer et al., 2000; Saarenpää-Heikkilä et al., 1995; Sarchiapone et al., 2014; Wasserman, 2016). W badaniach różnych populacji dziecięcych zaburzenia snu dotyczyły $25-62 \%$ osób, a w badaniach populacji polskich dzieci częstość zaburzeń snu mieściła się w przedziale 19-67\% (Kaczor i Skalski, 2016). 
The aim of the present paper was carrying out an analysis of selected parameters of sleep among students of secondary schools with taking into consideration sex and age. The authors tried to demonstrate differences in the occurrence of problems with sleep between boys and girls and between younger and older adolescents. The following assumptions were made:

- Problems with sleep will be a frequent problem in the studied population.

- More problems with sleep will occur in the group of older adolescents.

- Girls will report more sleep disorders.

Sleep disorders are an important problem because an insufficient quantity and quality of sleep results in somatic, psychical and social consequences (Kaczor and Skalski, 2016).

\section{MATERIAL AND METHODS}

The study enrolled students of three randomly selected public secondary schools located in various districts of Łódź. These were students from all levels of education, i.e. from grades 1 to 3 - one class from every level was selected in a draw. A week before the study the teachers of these classes attended educational training in the field of the hygiene and disorders of sleep. Next the trained teachers carried out a one-time questionnaire survey among the students aimed ad assessing certain parameters of sleep. The students filled in the questionnaires during one of the lessons. They provided answers to nearly $100 \%$ of questions included in the questionnaire.

In total the study examined 125 persons aged $12-18$, including 70 boys (56\%) and 55 girls (44\%). The mean age of the surveyed subjects was 14 years and 11 months and the standard deviation was 12 months.

The Bioethical Committee of the Medical University of Lodz provided consent for carrying out the study (number RNN/49/07/KE).

The students filled in the Sleep Disorders Assessment Questionnaire (Appendix 1), drafted for the needs of a wider examination at the Department of Adolescent Psychiatry of the Medical University of Lodz. A review of literature (American Academy of Sleep Medicine, 2005; American Psychiatric Association, 1994; Międzynarodowa Statystyczna Klasyfikacja Chorób i Problemów Zdrowotnych, rewizja 10, 2000) allowed for selecting 18 variables which were included in the questionnaire. Thirteen questions referred to variables associated with sleep: the study assessed symptoms of insomnia, excessive sleepiness and disorders of the rhythm of sleep and wakefulness. Three questions referred to factors disrupting sleep and two - to taking hypnotic drugs.

The variables associated directly with sleep included: the occurrence of problems with sleep, the duration of problems with sleep, the number of hours of sleep at night, the regularity of going to sleep, the disrupted phase of sleep, sleep latency, waking up at night, the frequency of waking up,
Celem niniejszej pracy było przeprowadzenie analizy wybranych parametrów snu wśród uczniów szkół ponadpodstawowych z uwzględnieniem płci i wieku. Starano się wykazać różnice w występowaniu problemów ze snem między chłopcami i dziewczętami oraz między młodzieżą młodszą i starszą. Sformułowano następujące założenia:

- Kłopoty ze snem będą częstym problemem w badanej populacji.

- Więcej problemów ze snem wystąpi w grupie młodzieży starszej.

- Dziewczęta będą zgłaszały większą liczbę zaburzeń snu. Zaburzenia snu są ważnym problemem, gdyż niedostateczna ilość i jakość snu pociągają za sobą konsekwencje somatyczne, psychiczne i społeczne (Kaczor i Skalski, 2016).

\section{MATERIA I METODY}

W badaniu wzięli udział uczniowie trzech losowo dobranych publicznych szkół ponadpodstawowych z różnych dzielnic Łodzi. Byli to uczniowie ze wszystkich poziomów nauczania, czyli od 1. do 3. klasy - wylosowano po jednej klasie z każdego poziomu. Nauczyciele tych klas tydzień przed badaniem odbyli zajęcia edukacyjne dotyczące higieny i zaburzeń snu. Następnie przeszkoleni nauczyciele przeprowadzili wśród młodzieży jednorazowe badanie kwestionariuszowe służące ocenie określonych parametrów snu. Uczniowie wypełniali kwestionariusze podczas jednej $\mathrm{z}$ godzin lekcyjnych. W badaniu udało się uzyskać prawie 100-procentową liczbę odpowiedzi.

W sumie przebadano 125 osób w wieku 12-18 lat, w tym 70 chłopców (56\%) i 55 dziewcząt (44\%). Średnia wieku ankietowanych wynosiła 14 lat i 11 miesięcy, a odchylenie standardowe - 12 miesięcy.

$\mathrm{Na}$ badanie uzyskano zgodę Komisji Bioetycznej Uniwersytetu Medycznego w Łodzi (numer RNN/49/07/KE). Uczniowie wypełniali Kwestionariusz Oceny Zaburzeń Snu (załącznik 1), skonstruowany na potrzeby szerszego badania w Klinice Psychiatrii Młodzieżowej Uniwersytetu Medycznego w Łodzi. Na podstawie przeglądu literatury (American Academy of Sleep Medicine, 2005; American Psychiatric Association, 1994; Międzynarodowa Statystyczna Klasyfikacja Chorób i Problemów Zdrowotnych, rewizja 10, 2000) wytypowano 18 zmiennych, które zawarto w kwestionariuszu. Trzynaście pytań dotyczyło zmiennych związanych ze snem: oceniano objawy bezsenności, nadmiernej senności oraz zaburzenia rytmu snu i czuwania. Trzy pytania odnosiły się do czynników zakłócających sen, a dwa - do przyjmowania leków nasennych.

Do zmiennych związanych bezpośrednio ze snem należały: występowanie problemów ze snem, czas trwania problemów ze snem, liczba przesypianych godzin nocnych, regularność kładzenia się spać, zaburzona faza snu, latencja snu, wybudzanie się w nocy, częstość wybudzeń, powód wybudzeń, poczucie zbyt krótkiego snu, poczucie zmęczenia 


\begin{tabular}{|c|c|c|c|c|c|c|c|c|c|c|}
\hline \multirow{2}{*}{$\begin{array}{l}\text { Reasons for waking up } \\
\text { Powody wybudzeń } \\
\text { Noise } \\
\text { Hałas }\end{array}$} & \multicolumn{2}{|c|}{$\begin{array}{c}\text { In Total } \\
\text { Razem }\end{array}$} & \multicolumn{2}{|c|}{$\begin{array}{l}\text { Boys } \\
\text { Chłopcy }\end{array}$} & \multicolumn{2}{|c|}{$\begin{array}{c}\text { Girls } \\
\text { Dziewczęta }\end{array}$} & \multicolumn{2}{|r|}{ WA } & \multicolumn{2}{|r|}{$P A$} \\
\hline & 4 & $5.97 \%$ & 1 & $2.86 \%$ & 3 & $9.38 \%$ & 2 & $8.00 \%$ & 2 & $4.76 \%$ \\
\hline $\begin{array}{l}\text { Dreams } \\
\text { Sny }\end{array}$ & 2 & $2.99 \%$ & 1 & $2.86 \%$ & 1 & $3.13 \%$ & 0 & $0.00 \%$ & 2 & $4.76 \%$ \\
\hline $\begin{array}{l}\text { Nightmares } \\
\text { Koszmary senne }\end{array}$ & 10 & $14.93 \%$ & 3 & $8.57 \%$ & 7 & $21.88 \%$ & 4 & $16.00 \%$ & 6 & $14.29 \%$ \\
\hline $\begin{array}{l}\text { Hunger } \\
\text { Głód }\end{array}$ & 2 & $2.99 \%$ & 2 & $5.71 \%$ & 0 & $0.00 \%$ & 0 & $0.00 \%$ & 2 & $4.76 \%$ \\
\hline $\begin{array}{l}\text { Toilet } \\
\text { WC }\end{array}$ & 17 & $25.37 \%$ & 13 & $37.14 \%$ & 4 & $12.50 \%$ & 5 & $20.00 \%$ & 12 & $28.57 \%$ \\
\hline \begin{tabular}{|l} 
Thirst \\
Picie
\end{tabular} & 11 & $16.42 \%$ & 4 & $11.43 \%$ & 7 & $21.88 \%$ & 1 & $4.00 \%$ & 10 & $23.81 \%$ \\
\hline $\begin{array}{l}\text { School stress } \\
\text { Stres szkolny }\end{array}$ & 5 & $7.46 \%$ & 3 & $8.57 \%$ & 2 & $6.25 \%$ & 5 & $20.00 \%$ & 0 & $0.00 \%$ \\
\hline $\begin{array}{l}\text { Scratching cat, creaking floor } \\
\text { Drapiqcy kot, skrzypiqca podłoga }\end{array}$ & 1 & $1.49 \%$ & 1 & $2.86 \%$ & 0 & $0.00 \%$ & 1 & $4.00 \%$ & 0 & $0.00 \%$ \\
\hline $\begin{array}{l}\text { Anxiety } \\
\text { Lęk }\end{array}$ & 1 & $1.49 \%$ & 1 & $2.86 \%$ & 0 & $0.00 \%$ & 0 & $0.00 \%$ & 1 & $2.38 \%$ \\
\hline $\begin{array}{l}\text { Falling down from bed } \\
\text { Spadanie z tózka }\end{array}$ & 2 & $2.99 \%$ & 2 & $5.71 \%$ & 0 & $0.00 \%$ & 0 & $0.00 \%$ & 2 & $4.76 \%$ \\
\hline $\begin{array}{l}\text { Unfavourable temperature of the surroundings } \\
\text { Zła temperatura otoczenia }\end{array}$ & 3 & $4.48 \%$ & 1 & $2.86 \%$ & 2 & $6.25 \%$ & 1 & $4.00 \%$ & 2 & $4.76 \%$ \\
\hline \multirow[t]{2}{*}{$\begin{array}{l}\text { Lack of reason } \\
\text { Brak przyczyny }\end{array}$} & 9 & $13.43 \%$ & 3 & $8.57 \%$ & 6 & $18.75 \%$ & 6 & $24.00 \%$ & 3 & $7.14 \%$ \\
\hline & 67 & & 35 & & 32 & & 25 & & 42 & \\
\hline
\end{tabular}

Tab. 1. The reasons for waking up at night mentioned by students confirming the occurrence of sleep problems

Tab. 1. Powody wybudzania nocnego podawane przez uczniów potwierdzających występowanie problemów ze snem

the reason for waking up, the feeling of too short sleep, the feeling of tiredness during the day, the feeling of sleepiness during the day, the feeling of shallowing of sleep.

The variables disrupting sleep included: problems with mental health occurring in the past, chronic somatic diseases (Avidan and Zee, 2007; Owens and Witmans, 2004), taking psychoactive substances in the last month.

Variables associated with hypnotic drugs were taking hypnotic drugs in the last month and the frequency of taking hypnotic drugs.

Some of the questions were open - the young people were asked to provide descriptive answers. These questions referred to the reason for waking up at night (Tab. 1) and the frequency of taking hypnotic drugs (Tab. 2). Not all of the study participants answered the open questions. w ciągu dnia, poczucie senności w ciągu dnia, poczucie spłycenia snu.

Wśród zmiennych zakłócających sen wyróżniono: problemy ze zdrowiem psychicznym występujące w przeszłości, przewlekłe choroby somatyczne (Avidan i Zee, 2007; Owens i Witmans, 2004), zażywanie substancji psychoaktywnych w ostatnim miesiącu.

Zmienne związane z lekami nasennymi to zażywanie leków nasennych w ostatnim miesiącu i częstotliwość zażywania leków nasennych.

Niektóre pytania miały charakter otwarty - młodzież poproszono o udzielanie odpowiedzi opisowych. Pytania te dotyczyły powodu wybudzenia nocnego (tab. 1) oraz częstości zażywania leków nasennych (tab. 2). Nie wszyscy uczestnicy odpowiedzieli na pytania otwarte.

\begin{tabular}{|c|c|c|c|c|c|c|c|c|c|c|}
\hline \multirow[b]{2}{*}{$\begin{array}{l}\text { Occasionally } \\
\text { Sporadycznie }\end{array}$} & \multicolumn{2}{|c|}{$\begin{array}{c}\text { In total } \\
\text { Razem }\end{array}$} & \multicolumn{2}{|c|}{$\begin{array}{l}\text { Boys } \\
\text { Chtopcy }\end{array}$} & \multicolumn{2}{|c|}{$\begin{array}{c}\text { Girls } \\
\text { Dziewczęta }\end{array}$} & \multicolumn{2}{|r|}{ WA } & \multicolumn{2}{|r|}{ PA } \\
\hline & 3 & $60.00 \%$ & 2 & $100.00 \%$ & 1 & $33.33 \%$ & 3 & $75.00 \%$ & 0 & $0.00 \%$ \\
\hline \begin{tabular}{|l|} 
2-3 times/week \\
$2-3$ razy/tydzień
\end{tabular} & 2 & $40.00 \%$ & 0 & $0.00 \%$ & 2 & $66.67 \%$ & 1 & $25.00 \%$ & 1 & $100.00 \%$ \\
\hline
\end{tabular}

WA - the group of early adolescents (aged 12-14); PA - the group of late adolescents (aged 15-18).

WA - grupa wczesnych adolescentów (12-14 lat); PA - grupa późnych adolescentów (15-18 lat).

Tab. 2. The frequency of taking hypnotic drugs by the students

Tab. 2. Częstość zażywania leków nasennych przez uczniów 
The assessment of all the variables was performed on the basis of the studied person's subjective assessment. The students determined on their own whether they experience problems with sleep and for how long these problems had been persisting.

Besides dividing the students according to sex (the group of girls and that of boys), two age groups were differentiated in the study: persons aged 12-14 - the group of early adolescents (WA) and persons aged 15-18 - the group of late adolescents (PA) (Namysłowska, 2012; Piotrowski et al., 2014a, 2014b). The WA group included 49 persons (39.20\%), group PA - 76 persons $(60.80 \%)$. Due to the limitations of the questionnaire study, the hour when the studied persons go to sleep was not taken into consideration in the questions, thus it was not possible to assess the differentiation between the group of younger and older adolescents nor the differentiation in the time of going to sleep between school working days and student-free-days (which is significant for assessing sleep rhythm disorders, DSWPD).

The statistical analysis of differences in the scope of sleep parameters included in the Sleep Disorders Assessment Questionnaire between the differentiated groups of students - girls and boys as well as early and late adolescents - was carried out using the Chi-square test, the Yates-corrected Chi-square test and Fisher's exact test. The accepted significance level was $p<0.05$.

\section{RESULTS}

\section{The description of selected parameters of sleep of the studied population of students}

The data presented in Tab. 3 indicate that one in three studied persons (34.4\%) reported the occurrence of problems with sleep. Over a half of the students confirming problems with sleep (60.5\% out of $n=43$ ) reported that these problems had been persisting for over a month. Moreover, over a half of all the surveyed subjects declared that they sleep less than 8 hours during one night. Nearly half of the students (44\%) did not go to sleep regularly at the same time and had a prolonged sleep latency (the time in which $43.2 \%$ of students fell asleep was over 20 minutes). The most frequently reported problem was the feeling of too short sleep (67.2\% of the studied persons), however, only one in five students experienced problems with waking up in the morning. Nearly half of those surveyed (43.2\%) claimed that they wake up at night but only a few percent of persons perceived this as a problem. The majority of students woke up once or twice during the night. Over a half of the studied subjects (56.8\%) felt tired or sleepy during the day. Nearly $40 \%$ had the feeling of too shallow sleep. A few percent of the study participants reported that currently or in the past they experienced problems with mental health or that they took hypnotic drugs. One in four of the studied
Oceny wszystkich zmiennych dokonywano na podstawie subiektywnej oceny badanego. Uczniowie sami określali, czy występują u nich problemy ze snem i od jak dawna się utrzymują.

Oprócz podziału uczniów ze względu na płeć (grupa dziewcząt i grupa chłopców) w badaniu wyodrębniono dwie grupy wiekowe: 12-14 lat - grupa wczesnych adolescentów (WA) oraz 15-18 lat - grupa późnych adolescentów (PA) (Namysłowska, 2012; Piotrowski et al., 2014a, 2014b). Grupa WA liczyła 49 osób $(39,20 \%)$, grupa PA - 76 osób $(60,80 \%)$. Z uwagi na ograniczenia badania kwestionariuszowego nie uwzględniono w pytaniach pory kładzenia się spać, nie można więc było ocenić zróżnicowania między grupą młodszej i starszej młodzieży ani zróżnicowania pory kładzenia się spać między dniami szkolnymi i dniami wolnymi od zajęć szkolnych (co jest istotne dla oceny zaburzeń rytmu snu, DSWPD).

Analiza statystyczna różnic w zakresie parametrów snu zawartych w Kwestionariuszu Oceny Zaburzeń Snu między wyodrębnionymi grupami uczniów - dziewcząt i chłopców oraz wczesnych i późnych adolescentów - została przeprowadzona za pomocą testu chi-kwadrat, testu chi-kwadrat Yatesa i dokładnego testu Fischera. Za poziom istotności przyjęto $p<0,05$.

\section{WYNIKI}

\section{Opis wybranych parametrów snu badanej populacji uczniów}

$\mathrm{Z}$ danych prezentowanych w tab. 3 wynika, że co trzeci ankietowany $(34,4 \%)$ zgłosił występowanie problemów ze snem. Ponad połowa uczniów potwierdzających problemy ze snem $(60,5 \%$ z $n=43)$ podała, że utrzymują się one dłużej niż miesiąc. Poza tym ponad połowa wszystkich ankietowanych zadeklarowała, iż sypia mniej niż 8 godzin w ciągu jednej nocy. Blisko co drugi uczeń (44\%) nie kładł się spać regularnie w tych samych godzinach i miał wydłużoną latencję snu (43,2\% uczestników zasypiało ponad 20 minut). Najczęstszym zgłaszanym problemem było poczucie zbyt krótkiego snu (67,2\% badanych), jednak tylko co piąty uczeń doświadczał trudności z porannym budzeniem się. Blisko połowa ankietowanych $(43,2 \%)$ stwierdziła, że wybudza się w nocy, ale jedynie dla kilku procent osób stanowiło to problem. Większość uczniów wybudzała się raz bądź dwa razy na noc. Ponad połowa $(56,8 \%)$ czuła się zmęczona bądź senna w ciągu dnia. Blisko 40\% badanych miało poczucie zbyt płytkiego snu. Kilka procent uczestników zgłosiło, że występowały u nich problemy ze zdrowiem psychicznym lub że zażywali leki nasenne. Co czwarty badany cierpiał na jakąś chorobę somatyczną i również co czwarty sięgał po substancje psychoaktywne.

Zażywanie leków nasennych zgłosiło jedynie pięć osób, byli to zarówno chłopcy, jak i dziewczęta. Troje z nich sięgało po leki nasenne jedynie sporadycznie, a dwie osoby potwierdziły, że korzystają z leków nasennych kilka razy 
subjects suffered from some somatic disease and also one in four persons used psychoactive substances.

Taking hypnotic drugs was reported only by five persons, these were both boys and girls. Three of them used hypnotic drugs only occasionally and two persons confirmed that they use hypnotic drugs several times during the week. Four of these students belonged to the WA group (Tab. 2).

\section{Comparison between the group of boys and of girls}

The analysis of the analysed variables (see Tab. 3) indicates that:

- Statistically significant differences were found in terms of having the feeling of too short sleep $(p=0.020)$, feeling tired during the day $(p=0.014)$ and feeling sleepy during the day $(p=0.001)$. In case of each of these parameters girls more frequently reported the occurrence of unfavourable phenomena.

- In terms of the remaining variables inter-group differences did not reach statistical significance, however, some differences were close to significance. This referred to the occurrence of sleep disorders $(p=0.054)$, more frequent among girls, waking up at night $(p=0.057)$, also more frequent among girls, and the number of times of waking up $(p=0.076)$ - boys woke up less frequently during a night.

Among descriptive variables, the most frequent reasons for waking up at night (Tab. 1) in the group of girls included nightmares, the need to have a drink, getting up to use the toilet, noise and school stress, and in the group of boys getting up to use the toilet, the need to have a drink, nightmares and school stress.

\section{Comparison between the group of early and of late adolescents}

The analysis of the analysed variables (see Tab. 3) indicates that:

- The group of early adolescents (WA) and the group of late adolescents (PA) proved to be more homogenous. Only one statistically significant difference was found - it refereed to using psychoactive substances $(p=0.0004)$, which were much more frequently used by students from the PA group.

- As for the remaining studied parameters, no statistically significant differences were found and the results did not even come close to the significance level.

In the WA group the main reported reason for waking up at night was the need to use the toilet and school stress $(20 \%$ out of $n=25)$ as well as nightmares (16\%) whereas in this respect the study participants from the PA group declared the need to use the toilet (28.6\%), the need to have a drink $(23.8 \%)$ and the next reason were nightmares (in 14.3\%). The fact that is striking is the frequent lack of an indicated w tygodniu. Czworo z tych uczniów należało do grupy WA (tab. 2).

\section{Porównanie grupy chłopców i grupy dziewcząt}

Z analizy badanych zmiennych (patrz tab. 3) wynika, że:

- Różnice istotne statystycznie odnotowano w zakresie poczucia zbyt krótkiego snu $(p=0,020)$, poczucia zmęczenia w ciągu dnia $(p=0,014)$ oraz poczucia senności w ciągu dnia $(p=0,001)$. W przypadku każdego z tych parametrów dziewczęta częściej zgłaszały występowanie niekorzystnych zjawisk.

- W zakresie pozostałych zmiennych różnice międzygrupowe nie osiągnęły istotności statystycznej, jednak niektóre różnice były bliskie istotności. Dotyczyło to występowania zaburzeń snu $(p=0,054)$, częstszego wśród dziewcząt, wybudzania się w nocy $(p=0,057)$, również częstszego wśród dziewcząt, oraz liczby wybudzeń $(p=0,076)$ - chłopcy wybudzali się mniejszą liczbę razy na noc.

Wśród zmiennych opisowych do najczęstszych przyczyn wybudzeń nocnych (tab. 1) w grupie dziewcząt należały koszmary senne, potrzeba napicia się, wstawanie do toalety, hałas i stres szkolny, natomiast w grupie chłopców wstawanie do toalety, potrzeba napicia się, koszmary senne i stres szkolny.

\section{Porównanie grup wczesnych i późnych adolescentów}

Z analizy badanych zmiennych (patrz tab. 3) wynika, że:

- Grupa wczesnych adolescentów (WA) i grupa późnych adolescentów (PA) okazały się bardziej homogenne. Wykazano tylko jedną różnicę istotną statystycznie dotyczyła ona używania substancji psychoaktywnych ( $p=0,0004)$, po które dużo częściej sięgali uczniowie $z$ grupy $P A$.

- Jeśli chodzi o pozostałe badane parametry, nie stwierdzono istotnych statystycznie różnic, a wyniki nie zbliżały się nawet do poziomu istotności.

W grupie WA jako główną przyczynę wybudzania nocnego podawano potrzebę skorzystania $\mathrm{z}$ toalety i stres szkolny $(20 \% \mathrm{z} n=25)$ oraz koszmary senne $(16 \%)$, natomiast uczestnicy z grupy PA poza potrzebą skorzystania z toalety $(28,6 \%)$ deklarowali potrzebę napicia się $(23,8 \%)$, a następnie koszmary senne (u 14,3\%). Zastanawia częsty brak podania przyczyn wybudzeń przez młodszych adolescentów: $20 \%$ vs $7 \%$ w grupie PA. Z uwagi na liczne braki w odpowiedziach nie oceniano różnic statystycznych w tym zakresie.

\section{OMÓWIENIE}

Wśród młodzieży szkolnej zaburzenia snu stanowią zauważalny problem: w prezentowanym badaniu trudności ze snem występowały u ponad 1/3 uczniów, co pokrywa się 


\begin{tabular}{|c|c|c|c|c|c|c|c|c|c|c|c|c|}
\hline \multirow[b]{2}{*}{$\begin{array}{l}\text { The occurrence of sleep disorders } \\
\text { Występowanie zaburzeń snu }\end{array}$} & \multicolumn{2}{|c|}{$\begin{array}{c}\text { In total } \\
\text { Razem }\end{array}$} & \multicolumn{2}{|c|}{$\begin{array}{l}\text { Boys } \\
\text { Chłopcy }\end{array}$} & \multicolumn{2}{|c|}{$\begin{array}{c}\text { Girls } \\
\text { Dziewczęta }\end{array}$} & \multirow{2}{*}{$\begin{array}{c}T(p) \\
3.713(0.054)\end{array}$} & \multicolumn{2}{|r|}{ WA } & \multicolumn{2}{|r|}{$P A$} & \multirow{2}{*}{$\begin{array}{c}T(p) \\
0.195(0.659)\end{array}$} \\
\hline & 43 & $34.40 \%$ & 19 & $27.14 \%$ & 24 & $43.64 \%$ & & 18 & $36.73 \%$ & 25 & $32.89 \%$ & \\
\hline $\begin{array}{l}\text { Duration of sleep disorders: a few days } \\
\text { Czas trwania zaburzeń snu: kilka dni }\end{array}$ & 8 & $18.60 \%$ & 5 & $26.31 \%$ & 3 & $12.50 \%$ & \multirow{3}{*}{$2.899(0.236)$} & 3 & $16.66 \%$ & 5 & $20.00 \%$ & \multirow{3}{*}{$0.089(0.956)$} \\
\hline $\begin{array}{l}\text { Duration of sleep disorders: less than a month } \\
\text { Czas trwania zaburzeń snu: mniej niż miesiqc }\end{array}$ & 9 & $20.93 \%$ & 2 & $10.52 \%$ & 7 & $29.16 \%$ & & 4 & $22.22 \%$ & 5 & $20.00 \%$ & \\
\hline $\begin{array}{l}\text { Duration of sleep disorders: more than a month } \\
\text { Czas trwania zaburzeń snu: więcej niż miesiqc }\end{array}$ & 26 & $60.46 \%$ & 12 & $63.16 \%$ & 14 & $58.33 \%$ & & 11 & $61.11 \%$ & 15 & $60.00 \%$ & \\
\hline $\begin{array}{l}\text { Hours of sleep during a night: }<\mathbf{8} \\
\text { Liczba przesypianych godzin nocnych: }<8\end{array}$ & 65 & $52.42 \%$ & 30 & $42.86 \%$ & 35 & $63.64 \%$ & \multirow{4}{*}{$5.787(0.122)$} & 17 & $34.69 \%$ & 39 & $51.31 \%$ & \multirow{4}{*}{$4.750(0.191)$} \\
\hline $\begin{array}{l}\text { Hours of sleep during a night: 8-10 } \\
\text { Liczba przesypianych godzin nocnych: } 8-10\end{array}$ & 56 & $45.16 \%$ & 37 & $52.86 \%$ & 19 & $34.55 \%$ & & 30 & $61.22 \%$ & 35 & $46.05 \%$ & \\
\hline $\begin{array}{l}\text { Hours of sleep during a night: }>10 \\
\text { Liczba przesypianych godzin nocnych: }>10\end{array}$ & 3 & $2.42 \%$ & 2 & $2.85 \%$ & 1 & $1.82 \%$ & & 2 & $4.08 \%$ & 1 & $1.32 \%$ & \\
\hline $\begin{array}{l}\text { Lack of data } \\
\text { Brak danych }\end{array}$ & 1 & $0.80 \%$ & 1 & $1.43 \%$ & 0 & $0.00 \%$ & & 0 & $0.00 \%$ & 1 & $1.32 \%$ & \\
\hline $\begin{array}{l}\text { Regularity of going to sleep } \\
\text { Regularnośćkładzenia się spać }\end{array}$ & 55 & $44.00 \%$ & 33 & $47.14 \%$ & 22 & $40.00 \%$ & $0.638(0.425)$ & 20 & $40.82 \%$ & 35 & $46.05 \%$ & $0.332(0.565)$ \\
\hline $\begin{array}{l}\text { Difficulties with falling asleep } \\
\text { Trudnościz zasypianiem }\end{array}$ & 16 & $12.80 \%$ & 10 & $14.29 \%$ & 6 & $10.91 \%$ & $0.315(0.575)$ & 5 & $10.20 \%$ & 11 & $14.47 \%$ & $0.487(0.485)$ \\
\hline $\begin{array}{l}\text { Difficulties with maintaining sleep } \\
\text { Trudności z utrzymaniem snu }\end{array}$ & 7 & $5.60 \%$ & 3 & $4.29 \%$ & 4 & $7.27 \%$ & $0.108(0.742)^{*}$ & 3 & $6.12 \%$ & 4 & $5.26 \%$ & $0.038(0.846)$ \\
\hline $\begin{array}{l}\text { Difficulties with waking up } \\
\text { Trudności z budzeniem się }\end{array}$ & 27 & $21.60 \%$ & 12 & $17.14 \%$ & 15 & $27.27 \%$ & $1.866(0.172)$ & 10 & $20.41 \%$ & 17 & $22.37 \%$ & $0.068(0.795)$ \\
\hline $\begin{array}{l}\text { Sleep latency: > } 20 \text { minutes } \\
\text { Latencja snu: > } 20 \text { minut }\end{array}$ & 54 & $43.20 \%$ & 29 & $41.43 \%$ & 25 & $45.45 \%$ & \multirow{3}{*}{$0.652(0.722)$} & 19 & $38.78 \%$ & 35 & $46.05 \%$ & \multirow{3}{*}{$2.664(0.264)$} \\
\hline $\begin{array}{l}\text { Sleep latency: 10-20 minutes } \\
\text { Latencja snu: } 10-20 \text { minut }\end{array}$ & 49 & $39.20 \%$ & 27 & $38.57 \%$ & 22 & $40.00 \%$ & & 18 & $36.73 \%$ & 31 & $40.79 \%$ & \\
\hline $\begin{array}{l}\text { Sleep latency: }<\mathbf{1 0} \text { minutes } \\
\text { Latencja snu: }<10 \text { minut }\end{array}$ & 22 & $17.60 \%$ & 14 & $20.00 \%$ & 8 & $14.55 \%$ & & 12 & $24.49 \%$ & 10 & $13.16 \%$ & \\
\hline $\begin{array}{l}\text { Waking up at night } \\
\text { Wybudzanie się w nocy }\end{array}$ & 54 & $43.20 \%$ & 25 & $35.71 \%$ & 29 & $52.73 \%$ & $3.633(0.057)$ & 21 & $42.86 \%$ & 33 & $43.42 \%$ & $0.004(0.950)$ \\
\hline $\begin{array}{l}\text { Frequency of waking up: } 1 \\
\text { (zesstość wybudzeń: } 1\end{array}$ & 20 & $35.09 \%$ & 13 & $44.83 \%$ & 7 & $25.00 \%$ & \multirow{4}{*}{$6.868(0.076)$} & 5 & $22.73 \%$ & 15 & $42.86 \%$ & \multirow{4}{*}{$3.271(0.352)$} \\
\hline $\begin{array}{l}\text { Frequency of waking up: } 2 \\
\text { Częstość wybudzeń: } 2\end{array}$ & 21 & $36.84 \%$ & 12 & $41.38 \%$ & 9 & $32.14 \%$ & & 11 & $50.00 \%$ & 10 & $28.57 \%$ & \\
\hline $\begin{array}{l}\text { Frequency of waking up: } 3 \\
\text { Częstość wybudzeń: } 3\end{array}$ & 11 & $19.30 \%$ & 2 & $6.90 \%$ & 9 & $32.14 \%$ & & 4 & $18.18 \%$ & 7 & $20.00 \%$ & \\
\hline $\begin{array}{l}\text { Frequency of waking up: }>3 \\
\text { Częstość wybudzeń: }>3\end{array}$ & 5 & $8.77 \%$ & 2 & $6.90 \%$ & 3 & $10.71 \%$ & & 2 & $9.09 \%$ & 3 & $8.57 \%$ & \\
\hline $\begin{array}{l}\text { Feeling of too short sleep } \\
\text { Poczucie zbyt krótkiego snu }\end{array}$ & 84 & $67.20 \%$ & 41 & $58.57 \%$ & 43 & $78.18 \%$ & $5.374(0.020)$ & 31 & $63.27 \%$ & 53 & $69.74 \%$ & $0.566(0.452)$ \\
\hline $\begin{array}{l}\text { Feeling tired during the day } \\
\text { Poczucie zmęczenia w ciagu dnia }\end{array}$ & 71 & $56.80 \%$ & 33 & $47.14 \%$ & 38 & $69.09 \%$ & $6.047(0.014)$ & 26 & $53.06 \%$ & 45 & $59.21 \%$ & $0.459(0.498)$ \\
\hline $\begin{array}{l}\text { Feeling sleepy during the day } \\
\text { Poczucie senności w ciggu dnia }\end{array}$ & 68 & $54.84 \%$ & 29 & $41.43 \%$ & 39 & $72.22 \%$ & $11.672(0.001)$ & 22 & $45.83 \%$ & 46 & $60.53 \%$ & $2.564(0.109)$ \\
\hline $\begin{array}{l}\text { Feeling of shallowed sleep } \\
\text { Poczucie sptycenia snu }\end{array}$ & 49 & $39.52 \%$ & 30 & $42.86 \%$ & 19 & $35.19 \%$ & $0.751(0.386)$ & 20 & $41.67 \%$ & 29 & $38.16 \%$ & $0.152(0.697)$ \\
\hline $\begin{array}{l}\text { Problems with mental health in the past } \\
\text { Problemy ze zdrowiem psychicznym w przeszłości }\end{array}$ & 4 & $3.23 \%$ & 2 & $2.86 \%$ & 2 & $3.70 \%$ & $(0.587)^{* *}$ & 3 & $6.25 \%$ & 1 & $1.32 \%$ & $(0.161)^{* *}$ \\
\hline $\begin{array}{l}\text { Taking hypnotic drugs } \\
\text { Zażywanie leków nasennych }\end{array}$ & 6 & $4.80 \%$ & 3 & $4.29 \%$ & 3 & $5.45 \%$ & $0.014(0.906)^{*}$ & 4 & $8.16 \%$ & 2 & $2.63 \%$ & $0.968(0.325)^{*}$ \\
\hline $\begin{array}{l}\text { Somatic diseases } \\
\text { Choroby somatyczne }\end{array}$ & 32 & $25.81 \%$ & 19 & $27.14 \%$ & 13 & $24.07 \%$ & $0.150(0.699)$ & 15 & $30.61 \%$ & 17 & $22.67 \%$ & $0.977(0.323)$ \\
\hline $\begin{array}{l}\text { Taking psychoactive substances } \\
\text { Zażywanie substancji psychoaktywnych }\end{array}$ & 33 & $26.61 \%$ & 20 & $28.57 \%$ & 13 & $24.07 \%$ & $0.316(0.574)$ & 4 & $8.16 \%$ & 29 & $38.67 \%$ & $12.601(0.0004)^{*}$ \\
\hline
\end{tabular}

Tab. 3. Particular parameters of sleep in the group of students taking into consideration sex - boys vs. girls - and age - early vs. late adolescents Tab. 3. Poszczególne parametry snu w grupie uczniów z uwzględnieniem płci - chłopcy vs dziewczęta - i wieku - wcześni vs późni adolescenci 
vs. $7 \%$ in the PA group. Due to numerous lacks of answer, the statistical differences were not assessed in this scope.

\section{DISCUSSION}

Sleep disorders constitute a noticeable problem among adolescents in school-age: in the presented study sleep difficulties occurred in over $1 / 3$ of students which is compliant with the lower intervals of the results of studies conducted in Poland and in the world (Kaczor and Skalski, 2016). In any of the compared groups (girls vs. boys, younger vs. older adolescents) the occurrence of problems with sleep did not exceed the level of $44 \%$ - most frequently these problems were reported by girls. Despite of the fact that the literature describes an increase of the frequency of sleep disorders associated with the period of puberty, the studies did not confirm differences in the frequency of problems with sleep in the group of early and late adolescents which were assumed at the beginning. However, it was demonstrated that sleep disorders frequently persist chronically (lasting over a month) already in teenagehood which may lead to the fixation of these disorders in the future. A substantial group of studied persons (over 52\%) had shorter sleeping times (less than 8 hours) than the recommended time of night sleep and did not go to sleep regularly at the same time. The biggest problem of the studied subjects was waking up in the morning which may be associated with the delay of the sleep phase frequently observed among adolescents. Also the prolonged sleep latency occurring in a high percentage of those studied may confirm the fact that the sleeping hours were delayed. In all the groups differentiated due to sex and age the adolescents declared the occurrence of waking up at night but girls reported waking up more frequently and they also woke up more times during the night. Girls also more frequently assessed their sleep as too short and they felt tired and sleepy during the day.

Despite of dividing the students into age groups the study did not reveal a higher percentage of persons with mental problems nor a higher amount of difficulties related to sleep in the group of late adolescents in relation to the group of early adolescents. Taking hypnotic drugs was a marginal phenomenon in all the studied groups.

It was found that girls and boys use psychoactive substances at a similar frequency and the problem of their usage increases among the teenagers together with age. However, it was not possible to demonstrate that more frequent taking of psychoactive substances deteriorates sleep parameters. Perhaps the studied students belittled the fact of smoking cigarettes, taking designer drugs or steroids or they did not want to reveal it. At the same time it is necessary to remember that there is a two-way relationship between external, disease factors (asthma, hypothyroidism, migraine, brain tumours, epilepsy) causing disruptions of sleep parameters and the consequences in the form of i.a. effects of provoked insomnia (lowering of the quality of life, de- z dolnymi przedziałami wyników badań prowadzonych w Polsce i na świecie (Kaczor i Skalski, 2016). W żadnej z porównywanych grup (dziewczęta $v s$ chłopcy, młodsi $v s$ starsi adolescenci) występowanie problemów ze snem nie przekraczało poziomu 44\% - najczęściej były one zgłaszane przez dziewczęta. Nie potwierdzono, jak zakładano na wstępie, różnic w częstości problemów ze snem w grupie wczesnych i późnych adolescentów, mimo że w literaturze opisywany jest wzrost częstości zaburzeń snu związany z okresem pokwitania. Wykazano jednak, iż zaburzenia snu już w wieku nastoletnim często utrzymują się przewlekle (ponad miesiąc), co może prowadzić do ich utrwalania się w przyszłości. Duża grupa badanych (ponad 52\%) sypiała krócej (poniżej 8 godzin), niż wynosi zalecana liczba godzin snu nocnego, i nie kładła się spać regularnie o tej samej porze. Największym problemem ankietowanych było poranne budzenie się, co może mieć związek z przesunięciem fazy snu, często obserwowanym wśród adolescentów. Również wydłużona latencja snu u dużego odsetka badanych może potwierdzać to, że godziny snu uległy przesunięciu. We wszystkich grupach wyodrębnionych ze względu na płeć i wiek młodzież deklarowała występowanie wybudzeń nocnych, ale częściej zgłaszały wybudzenia dziewczęta i one też wybudzały się większą liczbę razy w ciągu nocy. Dziewczęta częściej także oceniały swój sen jako zbyt krótki oraz czuły się zmęczone i senne w trakcie dnia.

Mimo podziału uczniów na grupy wiekowe nie odnotowano większego odsetka osób z problemami psychicznymi ani większej liczby trudności związanych ze snem w grupie późnych adolescentów w stosunku do grupy wczesnych adolescentów. Zażywanie leków nasennych było zjawiskiem marginalnym we wszystkich badanych grupach.

Stwierdzono, że dziewczęta i chłopcy podobnie często sięgają po środki psychoaktywne, a problem ich zażywania narasta wśród nastolatków z wiekiem. Nie udało się jednak wykazać, iż częstsze zażywanie substancji psychoaktywnych pogarsza parametry snu. Być może badani uczniowie bagatelizowali fakt palenia papierosów, przyjmowania dopalaczy czy sterydów albo nie chcieli go ujawniać. Należy przy tym pamiętać, że istnieje dwukierunkowa zależność między czynnikami zewnętrznymi, chorobowymi (astma, niedoczynność tarczycy, migrena, guzy mózgu, padaczka), warunkującymi zakłócenia parametrów snu, a konsekwencjami w postaci m.in. następstw sprowokowanej bezsenności (obniżenie jakości życia, depresja, lęk). Stany somatyczne wynikające z zaburzeń snu mogą przyczyniać się wtórnie do nasilenia bezsenności, z kolei bezsenność może warunkować inne stany somatyczne.

W omawianych badaniach nie pytano o występowanie określonych chorób somatycznych, które mogą mieć związek ze snem (np. wpływ zaburzeń snu na pogorszenie stanu zdrowia i vice versa w przebiegu otyłości czy zaburzeń krążenia). Co czwarty z badanych uczniów potwierdził, że choruje somatycznie (nieco częściej młodsi adolescenci). Szacuje się, iż miliony ludzi nie dosypia, a wśród młodzieży jest to szczególnie częste. Zapotrzebowanie na sen 
disruptions may secondarily contribute to the intensification of insomnia and in turn insomnia may cause other somatic conditions.

In the discussed studies the participants were not asked about the occurrence of certain somatic diseases which may be related to sleep (e.g. the influence of sleep disorders on the deterioration of the health condition and vice versa in the course of obesity or circulation disorders). One in four of the examined students confirmed suffering from a somatic disease (slightly more frequently younger adolescents). It is estimated that millions of people do not have enough sleep and this is especially common among adolescents. The need for sleep among teenagers is $8-10$ hours per day. Only such an amount of sleep guarantees proper functioning and, as is known, adolescents have a natural tendency for falling asleep and waking up later as well as for other risky behaviours. The consequence are physiological disorders (hypertension, gormandizing, headaches, muscular tension) and disorders related to learning (disorders of memory, attention) and to emotions (irritability, using alcohol and other substances, disorders of controlling impulses and behaviours), the most serious consequences of which are resignation thoughts and suicidal behaviours (Kothare and Scott, 2017; Sarchiapone et al., 2014).

\section{CONCLUSIONS}

In the presented study sleep disorders were reported by nearly a half of students, more frequently by girls. Girls also assessed the quality of their sleep worse: they more frequently perceived it as too short, they mentioned a higher number of cases of waking up at night, they felt less regenerated, more sleepy and tired during the day. The age of the studied subjects did not differentiate the frequency of occurrence of problems with sleep whereas older adolescents more frequently used psychoactive substances.

\section{Conflict of interest}

The authors do not report any financial or personal connections with other persons or organizations, which might negatively affect the contents of this publication and claim rights to it.

\section{References / Piśmiennictwo}

American Academy of Sleep Medicine: The International Classification of Sleep Disorders: Diagnostic \& Coding Manual. Second Edition (ICSD-2). American Academy of Sleep Medicine, Westchester, Illinois, 2005.

American Psychiatric Association: Diagnostic and Statistical Manual of Mental Disorders, Fourth Edition (DSM-IV). American Psychiatric Association, Washington 1994.

Avidan AY, Zee PC: Podręcznik medycyny snu. MediPage, Warszawa 2007

Doghramji K: The epidemiology and diagnosis of insomnia. Am J Manag Care 2006; 12 (Suppl): S214-S220.

Kaczor M, Skalski M: Rozpowszechnienie i konsekwencje bezsenności w populacji pediatrycznej. Psychiatr Pol 2016; 50: 555-569. u nastolatków wynosi 8-10 godzin na dobę. Dopiero ta długość snu zapewnia prawidłowe funkcjonowanie, a jak wiadomo, młodzież ma naturalną tendencję do późniejszego zasypiania i budzenia się, jak również do innych zachowań ryzykownych. W konsekwencji dochodzi do zakłóceń fizjologicznych (nadciśnienie, objadanie się, bóle głowy, napięcie mięśniowe) oraz tych związanych z uczeniem się (zaburzenia pamięci, uwagi) i emocjami (drażliwość, używanie alkoholu i innych substancji, zaburzenia kontroli impulsów i zachowań), których najpoważniejszymi konsekwencjami są myśli rezygnacyjne i zachowania samobójcze (Kothare i Scott, 2017; Sarchiapone et al., 2014).

\section{WNIOSKI}

W prezentowanym badaniu zaburzenia snu zgłaszała blisko połowa uczniów, częściej były to dziewczęta. One też gorzej oceniały jakość swojego snu: częściej uważały go za zbyt krótki, podawały większą liczbę wybudzeń w nocy, czuły się mniej zregenerowane, bardziej senne i zmęczone w ciągu dnia. Wiek badanych nie różnicował częstości występowania problemów ze snem, przy czym starsi adolescenci częściej sięgali po substancje psychoaktywne.

\section{Konflikt interesów}

Autorzy nie zgłaszaja żadnych finansowych ani osobistych powiązań z innymi osobami lub organizacjami, które moglyby negatywnie wplynać na treść publikacji oraz rościć sobie prawo do tej publikacji.

Kasperczyk J, Jośko J, Cichoń-Lenart A et al.: Epidemiologia zaburzeń snu u młodzieży mieszkającej na Górnym Śląsku. Sen 2006; 6: 8-13.

Kothare SV, Scott RQ: Sleep Disorders in Adolescents: A Clinical Casebook. Springer International Publishing, Switzerland 2017.

Krysiak-Rogala K, Jernajczyk W: Zaburzenia snu u dzieci i młodzieży z zaburzeniami i chorobami psychicznymi - zaburzenia afektywne i lękowe. Psychiatr Pol 2013; 47: 303-312.

Meijer AM, Habekothé HT, Van Den Wittenboer GL: Time in bed, quality of sleep and school functioning of children. J Sleep Res 2000; 9: 145-153.

Meltzer LJ, Mindell JA: Sleep and sleep disorders in children and adolescents. Psychiatr Clin North Am 2006; 29: 1059-1076.

Międzynarodowa Statystyczna Klasyfikacja Chorób i Problemów Zdrowotnych, rewizja 10 (ICD-10). Uniwersyteckie Wydawnictwo Medyczne „Vesalius”, Instytut Psychiatrii i Neurologii, Kraków-Warszawa 2000.

Namysłowska I (ed.): Psychiatria dzieci i młodzieży. Wydawnictwo Lekarskie PZWL, Warszawa 2012: 255-273.

Nowicki Z: Uwagi ogólne dotyczące problematyki snu. Sen 2002; 2 Supl A: A1-A6.

Owens JA, Witmans M: Sleep problems. Curr Probl Pediatr Adolesc Health Care 2004; 34: 154-179.

Piotrowski K, Wojciechowska J, Ziółkowska B: Rozwój nastolatka. Późna faza dorastania. Wiek: 14/15-19/20 lat. Instytut Badań Edukacyjnych, Warszawa 2014a.

Piotrowski K, Ziółkowska B, Wojciechowska J: Rozwój nastolatka. Wczesna faza dorastania. Wiek: 11/12-14/15 lat. Instytut Badań Edukacyjnych, Warszawa 2014b.

Saarenpää-Heikkilä OA, Rintahaka PJ, Laippala PJ et al.: Sleep habits and disorders in Finnish schoolchildren. J Sleep Res 1995; 4: 173-182. 
Sarchiapone M, Mandelli L, Carli V et al.: Hours of sleep in adolescents and its association with anxiety, emotional concerns, and suicidal ideation. Sleep Med 2014; 15: 248-254.

Urban M: Diagnostyka i leczenie zaburzeń snu u dzieci i młodzieży. Psychiatr Psychol Klin 2007; 7: 36-41.

Wasserman D: Review of health and risk-behaviours, mental health problems and suicidal behaviours in young Europeans on the basis of the results from the EU-funded Saving and Empower-

Appendix 1. Sleep Disorders Assessment Questionnaire in adolescents

Name and surname:

Age:

1. Do you feel that you have got sleep problems? YES NO

2. How long have you been experiencing sleep problems? $\begin{array}{llll}\text { A) A few days } & \text { B) Less than a month } & \text { C) Over a month }\end{array}$

3. How many hours do you usually sleep during a night?

4. Do you go to sleep regularly at the same time (on days on which you go to school)?

YES NO

5. Which phase of sleeping do you have most problems with? $\begin{array}{llll}\text { A) Falling asleep } & \text { B) Maintaining sleep } & \text { C) Waking up }\end{array}$

6. After what time do you usually fall asleep when you go to bed?
A) Less than $10 \mathrm{~min}$
B) $10-20 \mathrm{~min}$
C) Over $20 \mathrm{~min}$

7. Do you wake up during the night?

YES NO

8. If you wake up during the night then usually how many times?

9. Why do you wake up during the night? (If there is more than one reason, list the most important ones).

10. Do you have the feeling that you sleep too short? YES NO

11. Do you feel tired during the day?

YES NO

12. Do you feel sleepy during the day?

YES NO

13. Do you feel your sleep is shallowed?

YES NO

14. Have you ever had mental problems, have you been diagnosed by a psychiatrist or a psychologist or have you been treated psychiatrically?

YES NO

15. Do you take or have you ever taken hypnotic drugs? YES NO

16. If so - how often?

$\begin{array}{lll}\text { A) Every night } & \text { B) 2-3 times a week }\end{array}$

$\begin{array}{lll}\text { C) 2-3 times a month } & \text { D) Less frequently }\end{array}$

17. Do you suffer from any chronic diseases?

YES NO

18. Have you taken drugs or have you drank alcohol during the last month?

YES NO ing Young Lives in Europe (SEYLE) study. Psychiatr Pol 2016; 50: 1093-1107.

Yarcheski A, Mahon NE: A study of sleep during adolescence. J Pediatr Nurs 1994; 9: 357-367.

Załącznik 1. Kwestionariusz Oceny Zaburzeń Snu u młodzieży

Imię i nazwisko:

Wiek:

1. Czy czujesz, że masz problemy ze spaniem? TAK NIE

2. Od kiedy występują problemy ze spaniem?

$\begin{array}{lll}\text { A) Kilka dni } & \text { B) Krócej niż miesiąc } & \text { C) Ponad miesiąc }\end{array}$

3. Ile godzin sypiasz przeciętnie w ciągu nocy?

4. Czy kładziesz się regularnie o tej samej porze ( $w \mathrm{dni}$, w które chodzisz do szkoły)?

TAK NIE

5. Która faza snu sprawia Ci najwięcej problemów?
A) Zasypianie
B) Utrzymanie snu
C) Budzenie się

6. Po jakim czasie od położenia się spać $\mathrm{z}$ reguły zasypiasz?
A) Mniej niż $10 \mathrm{~min}$
B) $10-20 \mathrm{~min}$
C) Powyżej $20 \mathrm{~min}$

7. Czy wybudzasz się w ciągu nocy?

TAK NIE

8. Jeżeli wybudzasz się w nocy, to przeciętnie ile razy?

9. Dlaczego się wybudzasz w ciągu nocy? (Jeśli jest więcej powodów niż jeden, wymień najważniejsze).

10. Czy masz poczucie, że śpisz za krótko? TAK NIE

11. Czy czujesz się zmęczony w ciągu dnia? TAK NIE

12. Czy czujesz senność w ciągu dnia? TAK NIE

13. Czy czujesz, że Twój sen jest spłycony? TAK NIE

14. Czy kiedykolwiek miałeś problemy psychiczne, byłeś diagnozowany przez psychiatrę lub psychologa albo leczyłeś się psychiatrycznie?

TAK NIE

15. Czy zażywasz lub kiedykolwiek zażywałeś leki nasenne?

TAK NIE

16. Jeśli tak - jak często?
A) Co noc
B) 2-3 razy w tygodniu
C) 2-3 razy w miesiącu
D) Rzadziej

17. Czy chorujesz na jakieś choroby przewlekłe? TAK NIE

18. Czy w ciągu ostatniego miesiąca przyjmowałeś narkotyki lub alkohol?

TAK NIE 